\title{
Arıcılık ve Organik Bal Üretimi için Narman (Erzurum, Türkiye) Doğal Meralarında Ballı Bitki Potansiyeli
}

\author{
Honey Plant Potential of Natural Rangelands of Narman (Erzurum, Turkey) for Beekeeping \\ and Organic Honey Production
}

\author{
Mahir Murat CENGiZ* \\ Atatürk Üniversitesi, Erzurum Meslek Yüksekokulu, Bitkisel ve Hayvansal Üretim Bölümü, 25240, Erzurum
}

• Geliş tarihi / Received: 27.12.2017～• Düzeltilerek geliş tarihi / Received in revised form: 20.04.2018 • Kabul tarihi / Accepted: 27.04 .2018

\begin{abstract}
$\ddot{O} z$
Narman ilçesi, Türkiye'nin Doğu Anadolu Bölgesi'nde yer almaktadır. Ortalama rakım 1650 m, yıllık toplam yağış yaklaşık 420 mm'dir. Çalışma alanında ana ekonomik faaliyet hayvancılıktır ve hayvansal üretim meralara dayalı geleneksel olarak yapılır. Tarımı yapılan önemli bitki türleri patates, fasulye, tahıl, arpa ve yonca, korunga, fiğ gibi yem bitkileri olup, bölgede az miktarda mercimek ve şeker pancarı da üretilmektedir. Tarım faaliyetlerine ek olarak, arıclık ve bal üretimi de önemli bir tarımsal faaliyettir. Narman ilçesi, çok sayıda ballı bitki türü olan geniş doğal meralara sahiptir. Bölgedeki meralarda kimyasal gübreleme veya yabancı ot ve zararlı kontrolü için diğer kimyasal maddeler kullanılmadığından organik bal üretimi için önemli bir potansiyele sahiptir. Bölgede üretilen yüksek kaliteli organik bal, tüm ülke genelinde talep görmekte ve bal üreticileri, bal üretiminden önemli bir gelir elde etmektedir. Bu çalışma 20092011 yıllarında ilkbahar döneminde Erzurum ilinin Narman ilçesinin 14 farklı lokasyonunda yürütülmüştür. Florada, bal arıları için polen kaynağı olan baklagil çiçekli bitkilerin yanı sıra diğer çiçek açan bitki türleri de belirlenmiştir. Araştırma sahasında en fazla Yonca (Medicago sp), Kekik (Thymus sp), Civan perçemi (Achillea sp), Adaçayı (Salvia sp), Korunga (Onobrychis sp) ve Yabani çilek (Fragaria sp) türleri belirlenmiştir.
\end{abstract}

Anahtar kelimeler: Arıc1lı, Bal Arısı, Ballı Bitkiler, Meralar, Organik Bal

\begin{abstract}
Narman district is located at Eastern Anatolia Region of Turkey. The average altitude is $1650 \mathrm{~m}$, annual total precipitation is about $420 \mathrm{~mm}$. In study area, main economic activity is animal husbandry and animal production has made traditional practices, based on rangelands. Some important plant species are potato, beans, grain, barley and forage crop species such as alfalfa, sainfoin, vetch and also, in a small scale lentil and sugar beet has been produced in this regions. In addition to agricultural activity, beekeeping and honey production is another important agricultural activity. Narman district has wide natural rangelands with abundant honey plant species. Rangelands are important for organic honey production because in this vegetation, any chemical fertilization or other chemicals for weed and pest control never used. High-quality organic honey, produced in the region highly demands across all of the country and honey producers gain significant income from honey production. This study carried out, in years of 2009-2011, at 14 different locations of Narman district of Erzurum in the flowering time of natural plants. On natural flora, in addition to honey plant species, other flowering plant species were determined. In research area, it was determined the most common plant species were Alfalfa (Medicago sp), Thyme (Thymus sp), Yarrow (Achillea sp), Sage (Salvia sp), Sainfoin (Onobrychis sp) and Wild strawbery (Fragaria sp).
\end{abstract}

Keywords: Beekeeping, Honey Bee, Honey Plants, Rangelands, Organic Honey

* Mahir Murat CENGiZ; mcengiz@atauni.edu.tr; Tel: (0442) 23137 23; orcid.org/0000-0002-9844-4229 


\section{Giriş}

Üretim için çok fazla sermaye gerektirmemesi, toprak işlemeye gerek duymadan yapılabilmesi ve k1sa bir dönemde gelir elde edilmesi gibi avantajlarından dolayı günümüzde arıcılık; tüm dünyada en yaygın tarımsal faaliyetlerden birisidir. Tozlayıcılar, özellikle bal arıları, bitkisel üretim üzerine etkilerinden dolay1 karasal ekosistemler için oldukça önemlidirler (PatricioRoberto ve Campos, 2014). Bu durum yalnızca ekosistem açısından değil aynı zamanda ekonomik açıdan da oldukça faydalı etkilere sahiptir. Yapılan hesaplamalara göre bal arılarının tozlaştırması sonucu elde edilen ürün artışının ekonomik değerinin bal ve bal mumu gibi arı ürünlerinden elde edilenin yaklaşık 20 katı olduğu ifade edilmektedir (Genç ve Dodoloğlu, 2017). İnsan gıdası olarak kullanılan bitkilerin tamamına yakının 80 civarında bitki türünden sağlandığı ve bunların da büyük çoğunluğunun arılar tarafından tozlaştırılan bitkiler olduğu belirtilmektedir (Delaplane ve Mayer, 2000).

Arılar en önemli bitki tozlayıcıları olup, doğada yayılış gösteren çiçekli bitki türlerinden önemli bir kısmının arılar tarafindan ziyaret edildiği bilinmektedir (Kaufman, 1989). Varlıklarını devam ettirebilmek için birbirlerine ihtiyaç duyan arılar ve bitkiler arasında güçlü ortak bağlar kurulmuştur (Rathcke ve Jules, 1993). Arıların bitki çiçeklerini ziyaret etmelerinin asıl amacı nektar ve polen toplamak olup nektar ve polen arıların için karbonhidrat ve protein kaynağını oluşturmaktadır (Genç ve Dodoloğlu, 2017). Hem yabani hem de bal arılar, ekolojik ve ekonomik açıdan oldukça önemli olan tozlaşma için gerekli görevi yerine getirmektedirler (Delaplane and Mayer, 2000; Murray vd., 2009; Blaauw ve Isaacs., 2014; Campbell vd., 2017).

Çayır ve meralarda yaygın olarak bulunan yabancı tozlaşan baklagiller familyasına dahil bir çok bitki türü aynı zamanda arılar için de zengin birer besin kaynağıdır. Bal arılarının bir bitkiyi ziyaret etmesi bitkinin nektar ve polen üretimleri arasında doğru bir orantı vardır. (Genç ve Dodoloğlu, 2017). Doğal çayır ve meralar arılar için zengin nektar ve polen kaynağı durumunda olup bu alanlar organik arıcılık açısından da önemlidir. Doğu Anadolu bölgesi meraları gibi kimyasal ilaç ve gübre kullanımının yok denecek düzeyde olduğu doğal mera alanları büyük baş ve küçükbaş hayvancılığın yanı sıra arıcılık açısından da oldukça önemlidir.

Türkiye, 14,6 milyon hektarlık mera ve çayır alanına sahiptir ve bu alanların dağılımı bölgeler arasında büyük farklılıklar göstermektedir. Doğu Anadolu Bölgesi en geniş mera alanına sahip bölge olup ülke toplam mera alanının yaklaşık \%30'una sahipken Erzurum ilinin mera varlığı ise bölge meralarının \%50'sine denk gelmektedir (TUIK, 2017).

Doğal meralar insanlara, yabani ve evcil hayvanlara pek çok fayda sağlar. Hayvanlar için yem üretimi, biyolojik çeşitliliğin korunması ve toprak erozyonunun sinılandirılmasi, meraların bazı avantajlarıdır (Altin vd., 2005; Havstad vd., 2007; Holechek vd., 2011).

Meralar esasen Türkiye'de hayvan otlatmak için kullanılırlar ve özellikle ilkbahar, yaz ve sonbahar dönemlerinde hayvanların ana besin kaynağıdırlar. Ekstrem iklim koşulları ve topoğrafik yap1, bu bölgede bazı bitki türleri üretimini kısıtlamaktadır. $\mathrm{Bu}$ koşullar bölge insanını en önemli tarımsal faaliyetlerden biri olan hayvan yetiştiriciliğine yönlendirmiştir (Koç ve Gökkuş, 1996). Arıcılık, Türkiye ve özellikle herbisit veya böcek ilacı uygulanmayan geniş doğal mera alanlarına sahip Doğu Anadolu Bölgesinde meralara bağlı diğer önemli bir faaliyettir. $\mathrm{Bu}$ nedenle organik bal üretimi için doğal meralar oldukça uygun vejetasyonlardır (Cengiz vd., 2010). Arıcılık faaliyetini sadece bal üretimi için önemli olduğunu düşünmek doğru bir yaklaşım olmayacaktır, çoğu durumda arıların bitkileri tozlaşması bal üretiminin değerinden çok fazla olabilmektedir (Anon., 2017). ABD tarımına balarılarının çiçekli bitkilerin büyük bir çoğunluğunda tozlaşma olayını gerçekleştirerek yılda milyarlarca dolarlık gelir sağladığı ifade edilmektedir (Robinson vd., 1989). Tozlaşmanın ekonomiye olan katkısı dünya genelinde her yıl 200 milyar doların üzerinde olduğu tahmin edilmektedir (Gallai vd., 2009). Çünkü polinatörler, tohumla çoğalan pek çok bitki türünün çoğaltılması için gerekli olan tozlama hizmetlerini sağlayarak ekosistem yapısını ve fonksiyonunu sürdürmede kritik bir rol oynamaktadır (Kearns vd., 1998; Harmon vd., 2011; Pufal, vd., 2017). Ayrica, bal arılarının gerçek değerinin yaşam kalitesine çok yönlü katk1 sağlamasından kaynaklandığını ifade etmek daha doğru bir yaklaşım olacaktır (Kaluza vd., 2017).

Bölgedeki meralar zengin bitki türlerine sahiptir ve bu bitkilerin önemli bir kısmı arı türleri tarafından tozlaştırılmaktadır (Tokgöz vd., 2015). Narman'da, arıcılık ve bal üretimi esas olarak doğal meralara bağlı olarak yapılmaktadır (Şekil 1). $\mathrm{Bu}$ araştırmanın amacı Narman ilçesi tabii 
meralarının organik bal üretimi ve arıcılık açısından potansiyelini değerlendirmektir.

\section{Materyal ve Yöntem}

$\mathrm{Bu}$ çalışma, 2009-2011 yılları arasında Narman ilçesinin 14 değişik lokasyonunda gerçekleştiril- miştir (Tablo 1). Çalışmanın yürütüldüğü mera alanı ilçenin toplam mera alanının yüzde 20'sine denk gelen yaklaşık 10555, 28 hektarlık alandır. Çalışma yerleri farklı topoğrafik yapıya sahip olup erken ilkbahardan geç sonbahara kadar büyükbaş hayvanlar tarafindan otlatılmaktadır.

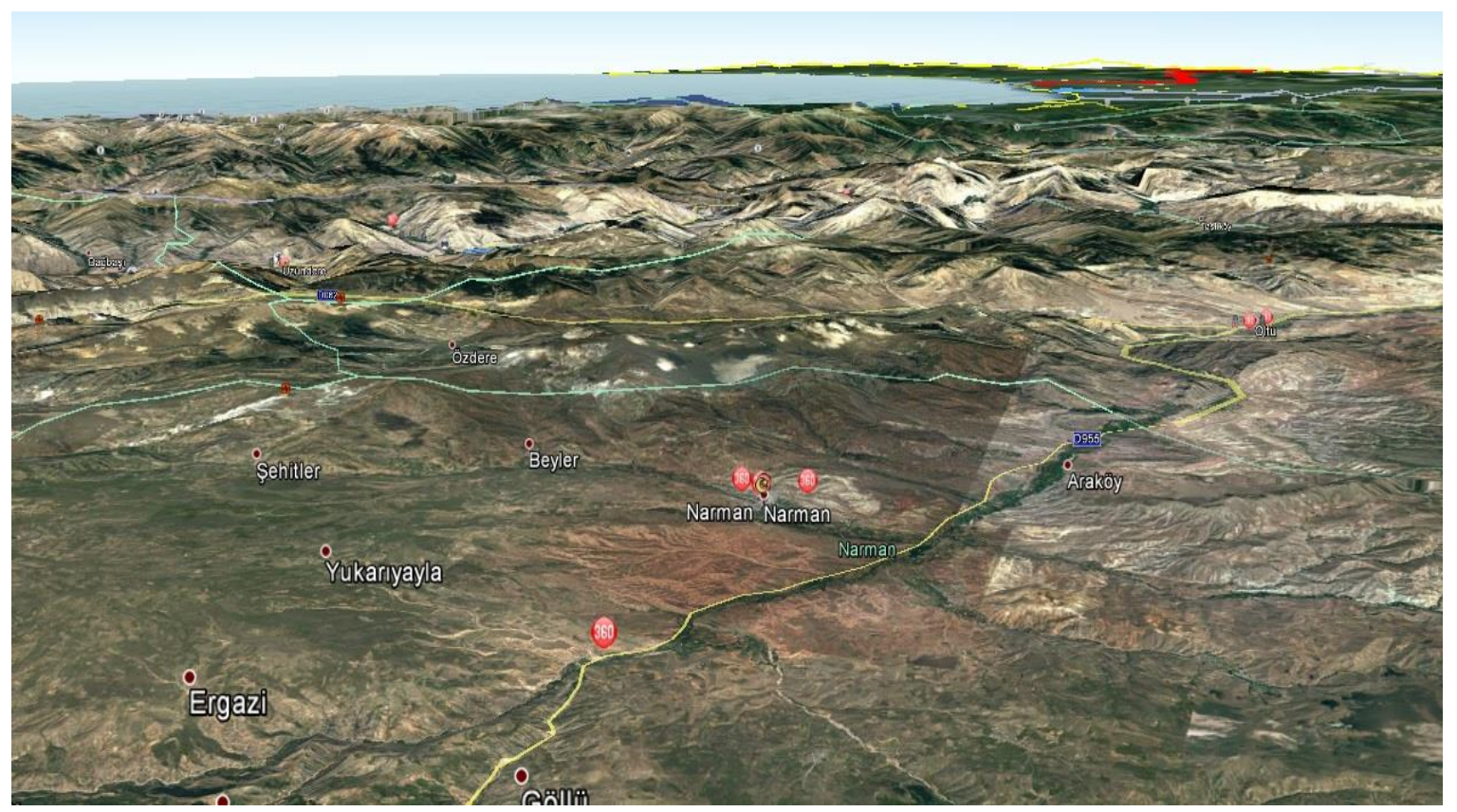

Şekil 1. Narman ilçesi uydu görünümü

Tablo 1. Çalışmanın yapıldığı mera alanları (lokasyonlar).

\begin{tabular}{llll}
\hline Çalışma alanları (Lokasyonlar) & Enlem & Boylam & Toplam mera alanı (da) \\
\hline 1. Narman (Tuzla) & $40^{\circ} 21^{\prime} 1.80^{\prime \prime} \mathrm{N}$ & $41^{\circ} 52^{\prime} 37.53^{\prime \prime} \mathrm{E}$ & 12563.428 \\
2. Narman (Meheng) & $40^{\circ} 21^{\prime} 42.43^{\prime \prime} \mathrm{N}$ & $41^{\circ} 55^{\prime} 22.46^{\prime \prime} \mathrm{E}$ & 5831.397 \\
3. Kuruçalı & $40^{\circ} 23^{\prime} 28.43^{\prime \prime} \mathrm{N}$ & $41^{\circ} 54^{\prime} 42.53 " \mathrm{E}$ & 4386.874 \\
4. Araköy & $40^{\circ} 22^{\prime} 56.72^{\prime \prime} \mathrm{N}$ & $41^{\circ} 56^{\prime} 28.04^{\prime \prime} \mathrm{E}$ & 1162.5 \\
5. Kışlaköy & $40^{\circ} 17^{\prime} 36.25^{\prime \prime} \mathrm{N}$ & $42^{\circ} 0^{\prime} 46.09^{\prime \prime} \mathrm{E}$ & 18847.543 \\
6. Serinsu & $40^{\circ} 21^{\prime} 16.99^{\prime \prime} \mathrm{N}$ & $41^{\circ} 59^{\prime} 47.22^{\prime \prime} \mathrm{E}$ & 2837.327 \\
7. Mahmutçavuş & $40^{\circ} 20^{\prime} 35.01^{\prime \prime} \mathrm{N}$ & $41^{\circ} 57^{\prime} 9.39^{\prime \prime} \mathrm{E}$ & 9299.08 \\
8. Yanıktaş & $40^{\circ} 16^{\prime} 21.03^{\prime \prime} \mathrm{N}$ & $41^{\circ} 51^{\prime} 44.24 " \mathrm{E}$ & 8996.825 \\
9. Göllü & $40^{\circ} 14^{\prime} 9.55^{\prime \prime} \mathrm{N}$ & $41^{\circ} 52^{\prime} 24.82^{\prime \prime} \mathrm{E}$ & 6762.992 \\
10. Kamı̈ı̈zü & $40^{\circ} 19^{\prime} 35.42^{\prime \prime} \mathrm{N}$ & $41^{\circ} 48^{\prime} 26.98^{\prime \prime} \mathrm{E}$ & 4367.52 \\
11. Karapınar & $40^{\circ} 17^{\prime} 12.97^{\prime \prime} \mathrm{N}$ & $41^{\circ} 41^{\prime} 42.55^{\prime \prime} \mathrm{E}$ & 6902.065 \\
12. Sapanlı & $40^{\circ} 20^{\prime} 36.32^{\prime \prime} \mathrm{N}$ & $41^{\circ} 45^{\prime} 44.05^{\prime \prime} \mathrm{E}$ & 5720.339 \\
13. Karadağ & $40^{\circ} 20^{\prime} 50.95^{\prime \prime} \mathrm{N}$ & $41^{\circ} 46^{\prime} 35.66^{\prime \prime} \mathrm{E}$ & 6671.703 \\
14. Beyler & $40^{\circ} 21^{\prime} 29.42^{\prime \prime} \mathrm{N}$ & $41^{\circ} 47^{\prime} 59.03 " \mathrm{E}$ & 11203.173 \\
\hline Toplam & & & $\mathbf{1 0 5 5 5 2 . 7 6 6}$ \\
\hline
\end{tabular}

Narman ilçesi yaklaşık 50.000 hektarlık mera alanına sahip olup bu doğal bitki örtüsü hayvan üreticileri tarafından otlatma amaçlı kullanılmaktadır. Hayvancılık yanında, arıcılık ve bal üretimi, meralar üzerinde yapılan başka bir faaliyettir. Her iki çalışma yılı Temmuz ayı başında, araştırma lokasyonlarının mera alanlarında botanik kompozisyonu belirlemek için transekt yöntemi (Canfield, 1941) kullanılmış ve bitki örtüsünü oluşturan bitki türleri ait oldukları 
familyalara göre tespit edilmiştir. Bitkilerin çiçeklenme periyodu boyunca her beş günde bir mera alanlarında gözlemler yapılmış ve sıkça bal arıları tarafından ziyaret edilen bitki türleri tespit edilmiştir.

\section{Bulgular Tartışma}

Çalışmanın sonuçlarına göre, tüm çalışma yerlerinde toplam 63 bitki türü tespit edilmiş ve 29 bitki türü, bal arıları tarafindan sıklikla ziyaret edilen çiçekli bitkiler olduğu belirlenmiştir. Tespit edilen bu bitkilerin büyük çoğunluğunun diğer familyalara ait olduğu belirlendi.

Baklagil türleri içerisinde yonca türüne (Medicago $s p$ ) bütün çalışma lokasyonlarda rastlanmış olup ikinci olarak en çok karşılaşılan baklagil türü dikenli geven türü (Astragalus lagurus) olup bu türe 6 lokasyonda rastlanmıştır. Çalışma lokasyonlarında rastlanan diğer baklagil türleri Sarı taşyoncası (Melilotus officinalis), Geven (Astragalus lineatus), Üçgül (Trifolium sp.), Gazal boynuzu (Lotus cornuculatus), Korunga (Onobrychis sp.), Taç otu (Coronilla sp.), Fiğ (Vicia sp) türleridir. Bu baklagil türü bitkilerinin sık sık bal arıları tarafından ziyaret edildiği görülmüştür. Baklagiller içerisinde Sarı taşyoncasının (Melilotus officinalis) bu bitkiler içinde en çok ziyaret edilen bitki türü olduğu gözlenmiştir. Bu bitki türünden sonra Korunga türü (Onobrychis sp) ve Yonca türü (Medicago $s p$.) ikinci olarak en çok ziyaret edilen bitki türleri olarak gözlenmiştir. Bu bitkilerin dışında sıklıkla ziyaret edilen bitki türleri diğer familyalara ait olup Geven türü (Artemisia spicigera) en s1k gözlenen tür olup Engerek otu (Echium sp.), Deliçay (Stachys sp.), Kekik türleri (Thymus sp.), Kirveotu (Teucrium sp.), Taş kekiği (Teucrium polium), Dağ reyhanı (Ziziphoria sp.) gibi diğer familyalara ait bitki türlerinin bal arıları tarafindan sıkça ziyaret edildiği gözlenmiştir. Çalışma yerinin botanik kompozisyonunda çiçekli bitki türlerinin oranı \% 78.87 (baklagil türleri + diğer familyalar) ve kalan bitki türü oranı\% 21.13 olarak hesaplanmıştır (Tablo 2).

Tablo 2. Çalışma yerlerinin botanik kompozisyonunda belirlenen ballı bitkiler ve oranları (\%).

\begin{tabular}{|c|c|c|c|c|c|c|c|c|c|c|c|c|c|c|c|}
\hline Türler & Lokas & yonlar & & & & & & & & & & & & & \\
\hline Baklagil & 1 & 2 & 3 & 4 & 5 & 6 & 7 & 8 & 9 & 10 & 11 & 12 & 13 & 14 & Ort. \\
\hline $\begin{array}{l}\text { Melilotus } \\
\text { officinalis }\end{array}$ & 8.62 & 0.00 & 0.00 & 0.00 & 0.00 & 0.00 & 0.00 & 0.00 & 0.00 & 8.11 & 0.00 & 29.41 & 10.53 & 17.40 & 5.29 \\
\hline Medicago sp & 90 & 17.00 & 19.20 & 23.54 & 14.46 & 10.10 & 3.12 & 17.08 & 11.11 & 8.11 & 16.66 & 20.59 & 12.28 & 15.22 & 13.96 \\
\hline $\begin{array}{l}\text { Astragalus } \\
\text { lineatus }\end{array}$ & 0.00 & 0.00 & 0.00 & 0.00 & 0.00 & 6.05 & 25.00 & 0.00 & 3.70 & 0.00 & 0.00 & 0.00 & 0.00 & 0.00 & 2.48 \\
\hline & 0.00 & 3.12 & 5.89 & 35.28 & 0.00 & 3.04 & 0.00 & 0.00 & 11.11 & 0.00 & 5.55 & 0.00 & 0.00 & 0.00 & 4.57 \\
\hline Trifolium sp. & 8.62 & 0.00 & 0.00 & 0.00 & 0.00 & 0.00 & 0.00 & 0.00 & 0.00 & 0.00 & 0.00 & 14.71 & 0.00 & 0.00 & 1.67 \\
\hline $\begin{array}{l}\text { Lotus } \\
\text { cornuculatus }\end{array}$ & 0.00 & 0.00 & 5.89 & 0.00 & 0.00 & 0.00 & 0.00 & 0.00 & 0.00 & 16.21 & 5.55 & 0.00 & 0.00 & 6.53 & 2.44 \\
\hline $\begin{array}{l}\text { Onobrychis } \\
\text { sp. }\end{array}$ & 15.52 & 0.00 & 0.00 & 0.00 & 0.00 & 9.09 & 0.00 & 0.00 & 0.00 & 2.70 & 0.00 & 0.00 & 10.53 & 0.00 & 2.70 \\
\hline $\begin{array}{l}\text { Coronilla } \\
\text { varia }\end{array}$ & 0.00 & 0.00 & 0.00 & 0.00 & 0.00 & 21.21 & 0.00 & 0.00 & 0.00 & 0.00 & 0.00 & 0.00 & 0.00 & 0.00 & 1.52 \\
\hline & 4.96 & 2.52 & 3.87 & 7.35 & 1.81 & 6.19 & 3.52 & 2.14 & 3.24 & 4.39 & 3.47 & 8.09 & 4.17 & 4.89 & 34.62 \\
\hline ürler & 1 & 2 & 3 & 4 & 5 & & 7 & & & 10 & 11 & 12 & 13 & 14 & Ort. \\
\hline $\begin{array}{l}\text { hilla } \\
\text { llefolium }\end{array}$ & 1.73 & 0.00 & 17.65 & 0.00 & 0.00 & 0.00 & 0.00 & 0.00 & 0.00 & 0.00 & 0.00 & 0.00 & 10.53 & 0.00 & 2.14 \\
\hline $\begin{array}{l}\text { Achilla } \\
\text { biebersteinii }\end{array}$ & 0.00 & 12.50 & 0.00 & 5.87 & 0.00 & 6.05 & 0.00 & 11.31 & 0.00 & 0.00 & 0.00 & 0.00 & 0.00 & 0.00 & 2.55 \\
\hline $\begin{array}{l}\text { mus } \\
\text { viflorus }\end{array}$ & 0.00 & 15.62 & 0.00 & 0.00 & 14.46 & 3.04 & 12.50 & 0.00 & 9.26 & 0.00 & 23.34 & 0.00 & 0.00 & 0.00 & 5.59 \\
\hline Stac & 0.00 & 0.00 & 0.00 & 0.00 & 3.61 & 3.04 & 0.00 & 6.31 & 0.00 & 0.00 & 0.00 & 20.59 & 0.00 & 0.00 & 2.40 \\
\hline $\begin{array}{l}\text { Stachys } \\
\text { iberica }\end{array}$ & 0.00 & 0.00 & 0.00 & 0.00 & 19.28 & 0.00 & 0.00 & 3.08 & 0.00 & 21.61 & 0.00 & 0.00 & 0.00 & 0.00 & 3.14 \\
\hline $\begin{array}{l}\text { Artemisia } \\
\text { spicigera }\end{array}$ & 19.30 & 0.00 & 0.00 & 11.77 & 0.00 & 0.00 & 10.76 & 9.23 & 16.66 & 8.11 & 0.00 & 2.95 & 0.00 & 0.00 & 5.63 \\
\hline Crepis sp & 0.00 & 9.37 & 0.00 & 0.00 & 9.28 & 3.04 & 0.00 & 3.08 & 0.00 & 0.00 & 11.11 & 0.00 & 0.00 & 0.00 & 2.56 \\
\hline $\begin{array}{l}\text { Campanula } \\
\text { stevenii }\end{array}$ & 0.00 & 0.00 & 0.00 & 0.00 & 0.00 & 0.00 & 0.00 & 0.00 & 0.00 & 0.00 & 0.00 & 0.00 & 8.77 & 0.00 & 0.63 \\
\hline $\begin{array}{l}\text { Helichyrsum } \\
\text { pallasii }\end{array}$ & 0.00 & 0.00 & 0.00 & 0.00 & 0.00 & 0.00 & 0.00 & 0.00 & 0.00 & 0.00 & 0.00 & 0.00 & 0.00 & 0.00 & 0.00 \\
\hline
\end{tabular}


Tablo 2'nin devam1.

\begin{tabular}{|l|l|l|l|l|l|l|l|l|l|l|l|l|l|l|l|}
\hline Diğer türler & 1 & 2 & 3 & 4 & 5 & 6 & 7 & 8 & 9 & 10 & 11 & 12 & 13 & 14 & Ort. \\
\hline $\begin{array}{l}\text { Fragaria } \\
\text { vesca }\end{array}$ & 8.79 & 15.62 & 0.00 & 11.77 & 1.20 & 0.00 & 0.00 & 0.00 & 7.41 & 0.00 & 0.00 & 0.00 & 0.00 & 0.00 & $\mathbf{3 . 2 0}$ \\
\hline Salvia sp. & 6.90 & 0.00 & 0.00 & 0.00 & 3.61 & 0.00 & 0.00 & 7.31 & 0.00 & 10.81 & 0.00 & 0.00 & 10.00 & 8.69 & $\mathbf{3 . 3 8}$ \\
\hline $\begin{array}{l}\text { Verbascum } \\
\text { sp. }\end{array}$ & 0.00 & 3.12 & 0.00 & 0.00 & 3.61 & 0.00 & 0.00 & 0.00 & 16.66 & 0.00 & 0.00 & 0.00 & 0.00 & 15.22 & $\mathbf{2 . 7 6}$ \\
\hline $\begin{array}{l}\text { Centaurea } \\
\text { pulcherima }\end{array}$ & 0.00 & 0.00 & 0.00 & 0.00 & 0.00 & 0.00 & 8.50 & 0.00 & 5.56 & 0.00 & 0.00 & 0.00 & 0.00 & 0.00 & $\mathbf{1 . 0 0}$ \\
\hline $\begin{array}{l}\text { Centaurea } \\
\text { sessilis }\end{array}$ & 0.00 & 0.00 & 0.00 & 0.00 & 0.00 & 0.00 & 0.00 & 0.00 & 0.00 & 0.00 & 0.00 & 0.00 & 0.00 & 0.00 & $\mathbf{0 . 0 0}$ \\
\hline $\begin{array}{l}\text { Eryngium } \\
\text { campestre }\end{array}$ & 1.73 & 0.00 & 0.00 & 11.77 & 0.00 & 0.00 & 12.50 & 0.00 & 0.00 & 0.00 & 0.00 & 0.00 & 0.00 & 0.00 & $\mathbf{1 . 8 6}$ \\
\hline $\begin{array}{l}\text { Cichorium } \\
\text { intybus }\end{array}$ & 0.00 & 0.00 & 0.00 & 0.00 & 0.00 & 0.00 & 0.00 & 0.00 & 0.00 & 0.00 & 0.00 & 0.00 & 8.77 & 10.87 & $\mathbf{1 . 4 0}$ \\
\hline $\begin{array}{l}\text { Centaurea } \\
\text { virgata }\end{array}$ & 0.00 & 0.00 & 0.00 & 0.00 & 0.00 & 0.00 & 12.50 & 0.00 & 5.56 & 0.00 & 0.00 & 0.00 & 0.00 & 0.00 & $\mathbf{1 . 2 9}$ \\
\hline Nepeta sp. & 0.00 & 0.00 & 0.00 & 0.00 & 0.00 & 0.00 & 0.00 & 0.00 & 1.85 & 0.00 & 0.00 & 0.00 & 12.28 & 0.00 & $\mathbf{1 . 0 1}$ \\
\hline $\begin{array}{l}\text { Teucrium } \\
\text { polium }\end{array}$ & 0.00 & 0.00 & 0.00 & 0.00 & 16.87 & 0.00 & 3.12 & 0.00 & 0.00 & 0.00 & 0.00 & 0.00 & 0.00 & 8.69 & $\mathbf{2 . 0 5}$ \\
\hline Ajuca sp. & 0.00 & 0.00 & 0.00 & 0.00 & 0.00 & 0.00 & 0.00 & 0.00 & 0.00 & 0.00 & 0.00 & 0.00 & 6.00 & 6.53 & $\mathbf{0 . 8 9}$ \\
\hline Circium sp. & 0.00 & 0.00 & 0.00 & 0.00 & 0.00 & 0.00 & 0.00 & 0.00 & 0.00 & 0.00 & 0.00 & 0.00 & 0.00 & 10.87 & $\mathbf{0 . 7 8}$ \\
\hline $\begin{array}{l}\text { Genel } \\
\text { Toplam }\end{array}$ & $\mathbf{1 . 8 3}$ & $\mathbf{2 . 6 8}$ & $\mathbf{0 . 8 4}$ & $\mathbf{1 . 9 6}$ & $\mathbf{3 . 4 3}$ & $\mathbf{0 . 7 2}$ & $\mathbf{2 . 8 5}$ & $\mathbf{1 . 9 2}$ & $\mathbf{3 . 0 0}$ & $\mathbf{1 . 9 3}$ & $\mathbf{1 . 6 4}$ & $\mathbf{1 . 1 2}$ & $\mathbf{2 . 6 8}$ & $\mathbf{2 . 9 0}$ & $\mathbf{4 4 . 2 5}$ \\
\hline Diğerleri & 1.56 & 1.69 & 2.90 & 0.77 & 0.97 & 1.95 & 0.86 & 2.90 & 0.79 & 1.74 & 2.70 & 0.84 & 0.74 & 0.00 & $\mathbf{2 0 . 4 1}$ \\
\hline
\end{tabular}

$\mathrm{Bu}$ çalışmanın sonuçlarına göre, Narman ilçesinde doğal meralar önemli bal özlü bitki türlerine sahiptir. Sahada 29 bitki türünün arlarca sik sık ziyaret edildiği gözlenmiștir. Bu bitki türlerinin arıcılık ve bal üretimi açısından önemli olduğu ifade edilmektedir (Tokgöz vd., 2015; Çöçen vd., 2014; Anon., 2017; Kaluza vd., 2017). Yapılan çalışmalarda, bal arılarının iklim ve coğrafi yapıya bağlı olarak floralarda yetişen farklı çiçekli bitkileri nektar ve polen kaynağı olarak tercih ettikleri bildirilmiştir (Morse ve Calderone, 2000; Özbek, 2011; Çöçen vd., 2014; Deveci vd., 2015) Bal arılarının nektar ve polen bakımından zengin olan bitkileri ziyaret etmelerinin sebepleri bitkileri tozlaştırmanın yanı sıra beslenmeleri için polen ve bal üretimi için nektar toplamaktır. Dolayısıyla arıların ziyaret ettikleri bitki türleri bal ve polen üretimi açısından belirli bir potansiyele sahip bitkiler olarak değerlendirilebilir.

\section{Sonuç}

Değişik faktörlerin etkisiyle bozulan ekosistemin doğal dengesini yeniden düzeltmeye yönelik yapılan faaliyetlerden biri olan organik tarımın; en önemli unsurları arasında bal arıları önemli bir yere sahiptir. Birçok bitki türünün gelecek nesillere genlerini aktarabilmesi ve bitki örtüsünün doğal vejetasyondaki çeşitliliğinde bal arılarının çok önemli bir rolü vardır. Bal arılarının organik tarımın önemli bir aktörü olarak değerlendirilmesi ve tozlaşmada yoğun bir şekilde kullanılması gerekir. $\mathrm{Bu}$ sayede doğal mera alanlarının nektar ve polen kaynakları arılar tarafından değerlendirilirken, diğer taraftan bu alanlardaki birçok bitki türünde kalite ve üretim miktarı artacaktır.

Çalışma sahasında saptanan çiçekli bitki türleri arıc1lık ve bal üretimi için oldukça önemli türlerdir. Narman'da çalışma alanlarının botanik kompozisyonunda çiçekli bitki türlerinin oranı \% 78,87 gibi yüksek bir oranda olduğu belirlenmiş̧ir. Araştırmada arılarca en çok ziyaret edilen bitki türlerinin yonca türü ve dikenli geven türü gibi baklagil bitkileri olduğu belirlenmiştir. Çalışma lokasyonlarında rastlanan diğer baklagil türleri Sarı taş yoncası (Melilotus officinalis), Gazal boynuzu (Lotus corniculatus), Korunga (Onobrychis sp), Taçotu (Coronilla sp.), Fĭg (Vicia $s p$ ) gibi baklağil türü bitkilerinin s1k s1k bal arıları tarafindan ziyaret edildiği tespit edilmiştir.

\section{Kaynaklar}

Altin, M., Gökkus, A., ve Koç, A., 2005. Çayır ve Mera Yönetimi, T.C. Tarım ve Köyişleri Bakanlığı Tarımsal Üretim ve Geliştirme Genel Müdürlügü Yayınları, Ankara.

Anonymous, 2017. Top Honey Plants for Producing the Best Honey, http://www.countryfarmlifestyles.com/honey-plants.html 
Blaauw, B. R. ve Isaacs, R. 2014. Flower plantings increase wild bee abundance and the pollination services provided to a pollination-dependent crop. Journal of Applied Ecology, 51(4), 890-898.

Campbell, A. J., Wilby, A., Sutton, P. ve Wäckers, F.L. 2017. Do sown flower strips boost wild pollinator abundance and pollination services in a spring-flowering crop? A case study from UK cider apple orchards. Agriculture, Ecosystems \& Environment, 239, 20-29.

Canfield, R.H., 1941. Application of the line interception method in sampling range vegetation. Journal of Forestry, 39(4), 388-394.

Cengiz., Genç, F. ve Dodoloğlu A., 2010. Arı ekoloji ilişkisi ve organik arıcılık, Türkiye I. Organik Hayvancilik Kongresi, Temmuz 2010, Gümüşhane, Türkiye, s. 52-57.

Çöçen, E., Özcan, E.T., Atay, S., Pala, M. ve Murathan, İ., 2014. Gümüşhane İli Merkez İlçe Köyleri Florasında Yoğun Olarak Bulunan Ballı Bitki Türleri ve Meraların Çiçeklenme Periyotları, Gümüşhane Üniversitesi Fen Bilimleri Enstitüsü Dergisi. 4(2), 126-133.

Delaplane, K.S. ve Mayer, D.F., 2000. Crop Pollination by Bees: CABI Publishing, University pres, Cambridge, 344p.

Deveci, M., Cinbırtoğlu, Ş. ve Demirkol, G., 2015. İlkbahar Dönemi Bitkileri ve Arıcılıkta Polen Kaynağı Bakımından Önemi. Akademik Ziraat Dergisi, 4(1),1-12.

Gallai, N., Salles, J., Settele, J. ve Vaissiere, B., 2009. Economic valuation of the vulnerability of world agriculture confronted with pollinator decline. Ecological Economics, 68, 810-821.

Genç, F. ve Dodoloğlu A., 2017, Arıcılığın Temel Esasları (Ders Notu): Atatürk Üniv. Zir. Fak. Yayınları, 341, Atatürk Üniv. Zir. Fak. Ofset Tesisi, Erzurum, 467s.

Harmon, J.P., Ganguli, A.C. ve Solga M.J., 2011. An overview of pollination in rangelands: Who, Why, and How By. Rangelands, 33(3), 4-8.
Havstad, K.M., Peters, D.P., Skaggs, R., Brown, J., Bestelmeyer, B., Fredrickson, E. ve Wright, J., 2007. Ecological services to and from rangelands of the United States. Ecological Economics, 64(2), 261-268.

Holechek J., Pieper, R.D. ve Herbel, C.H., 2011. Range management: principles and practices: 6. Ed. Prince Hall. USA, 456p.

Kaluza, B.F., Wallace, H., Keller, A., Heard, T.A., Jeffers, B., Drescher, N. ve Leonhardt, S.D., 2017. Generalist social bees maximize diversity intake in plant species-rich and resource-abundant environments. Ecosphere, 8(3), 1-19.

Kaufman, P.B., 1989. Biology and Importance: New York, Haber \& Row Publisher, 757p.

Kearns, C.A., Inouye, D.W. ve Waser, N.M., 1998. Endangered mutualisms: the conservation of plant-pollinator interactions. Annual review of ecology and systematics, 29(1), 83-112.

Koç, A. ve Gökkuş, A., 1996. Annual variation of above ground biomass, vegetation height and crude protein yield on the natural rangelands of Erzurum. Turkish Journal of Agriculture and Forestry, 20(4), 305-308.

Morse, R.A. ve Calderone, N.W. 2000. The value of honey bees as pollinators of US crops in 2000. Bee culture, 128(3), 1-15.

Murray, T.E., Kuhlmann, M. ve Potts, S.G., 2009. Conservation ecology of bees: populations, species and communities. Apidologie, 40(3), 211-236.

Özbek, H., 2011. Korunga (Onobrychis viciifolia Scop.): önemli bir arı bitkisi. Uludağ Arıcılık Dergisi, 2011(2), 51-56.

Patricio-Roberto, G.B. ve Campos, M.J. 2014. Aspects of Landscape and PollinatorsWhat is Important to Bee Conservation?. Diversity, 6(1), 158-175.

Pufal, G., Steffan-Dewenter, I. ve Klein, A.M., 2017. Crop pollination services at the landscape scale. Current Opinion in Insect Science, 21, 91-97. 
Rathcke, B.J. ve Jules, E.S., 1993. Habitat fragmentation and plant-pollinator interactions. Current Science, 65(3), 273-277.

Robinson, W.S., Nowogrodski, R. ve Morse, R.A., 1989. The value of honeybees as polinators of US crobs. American Bee Journal, 128(6), 411-423.
Tokgöz F., Angiş S. ve Şengül M., 2015. Palandöken Florası. Palandöken ilçe Gıda Tarım ve Hayvancılık Müdürlügü Yayınları, Erzurum, 245 s.

TUIKK, 2017. Türkiye'nin Çayır Mera Arazi Varlığı. Türkiye İstatistik Kurumu Verileri. www.tuik.gov.tr. 17 Aralık 2017. 